\title{
Constraining species-size class variability in rates of parrotfish bioerosion on Maldivian coral reefs: implications for regional-scale bioerosion estimates
}

\author{
Robert T. Yarlett ${ }^{1, *}$, Chris T. Perry ${ }^{1}$, Rod W. Wilson ${ }^{2}$, Kate E. Philpot ${ }^{3}$ \\ ${ }^{1}$ Geography, College of Life and Environmental Sciences, University of Exeter, Exeter EX4 4RJ, UK \\ ${ }^{2}$ Biosciences, College of Life and Environmental Sciences, University of Exeter, Exeter EX4 4QD, UK \\ ${ }^{3}$ Ecology by Design Ltd, Unit 16, Hampden House, Monument Park, Chalgrove, Oxfordshire OX44 7RW, UK
}

\begin{abstract}
Parrotfish are important bioeroders on coral reefs, and thus influence reef carbonate budgets and generate large volumes of carbonate sand that contribute to local beach and reef island maintenance. However, despite the importance of this process, there is a paucity of data with which variations in bioerosion rates as a function of species, feeding modes, and body size of parrotfish can be constrained. There is, in addition, limited knowledge regarding how resultant rates may vary within and between reef-building regions. Here, direct estimates of parrotfish bioerosion rates were quantified across different size classes of 6 common species of Maldivian parrotfish. These species comprise both 'scraper' and 'excavator' taxa, and our data indicate marked variations in mean bioerosion rates among these species. We also note that all species exhibited an apparent bimodal feeding cycle, with peaks in the late morning and early afternoon. Highest bioerosion rates were found in the 'excavator' Chlorurus strongylocephalus ( $460 \mathrm{~kg}$ ind. $\left.{ }^{-1} \mathrm{yr}^{-1}\right)$, nearly 130 times greater than rates calculated for comparably sized $(>45 \mathrm{~cm})$ 'scraper' species. Our data provide metrics that can be used in conjunction with parrotfish biomass or density data to improve estimates of parrotfish bioerosion on central Indian Ocean reefs, a region of high parrotfish density, but from which only limited metrics exist. We emphasise the importance of obtaining sub-regional scale process data to better inform estimates of reef bioerosion, especially to support attempts to model the impacts of fishing pressure, which commonly results in removal of high-rate bioeroding taxa.
\end{abstract}

KEY WORDS: Parrotfish $\cdot$ Bioerosion $\cdot$ Maldives $\cdot$ Coral reefs

\section{INTRODUCTION}

The structural complexity and growth potential of coral reefs underpin many reef ecosystem services, such as shoreline protection, and habitat provision for a diverse array of marine organisms, including many commercially important species (Lugo-Fernández et al. 1998, Moberg \& Folke 1999, Ruckelshaus et al. 2013, Ferrario et al. 2014). These systems are

*Corresponding author: yarlett.r@gmail.com shaped by a combination of biological, physical, and chemical constructional and erosional processes (Scoffin 1992, Perry \& Hepburn 2008). Framework construction is primarily the result of the production of carbonate skeletons by corals, while the most pervasive form of erosion is that by bioeroding organisms. This leads to weakening or erosion of the reef substrate (Stearn et al. 1977, Scoffin et al. 1980, Glynn 1997). Assessments of rates of carbonate accu-

() The authors 2018. Open Access under Creative Commons by Attribution Licence. Use, distribution and reproduction are unrestricted. Authors and original publication must be credited. 
mulation (e.g. by corals and coralline algae, and by sediment producers such as Halimeda spp. and Foraminifera), less that lost through bioerosion (e.g. by fish, urchins, sponges, and microborers) can thus be used to measure reef carbonate budgets (sensu Perry et al. 2008), which can provide an indication of net reef framework accumulation or loss. As a result, carbonate budget assessments are becoming increasingly relevant in the light of recent global coral bleaching events, which have caused large-scale coral mortality in a number of regions (Hughes et al. 2017), and with potential negative impacts on reef growth capacity (Perry \& Morgan 2017).

On the erosional side of the carbonate budget question, parrotfish (family Labridae) are often identified as especially important bioeroders (e.g. Bellwood et al. 2003, Perry et al. 2015a). Whilst feeding primarily on dead coral and rubble substrates (Bruggemann et al. 1994a, Bellwood 1995b, Afeworki et al. 2011), many parrotfish take bites out of the reef framework, likely targeting cyanobacteria (Clements et al. 2016). This framework material is ingested along with organic matter, broken down by modified gill arch elements known as the pharyngeal mill (Bellwood \& Choat 1990, Carr et al. 2006), processed in the gut, and egested as sediment (Bellwood 1995b, 1996, Morgan \& Kench 2016). These parrotfish can be categorised into 'scraping' or 'excavating' feeding modes, which are defined based on their musculoskeletal systems around the jaw, and feeding behaviour (Bellwood \& Choat 1990). These bioerosion and sediment-generation processes are increasingly recognised not only as an important component in coral reef carbonate budgets (Perry et al. 2014), but also as an important source of sediment to both reef and lagoonal sediments (Scoffin et al. 1980), and to reef-associated landforms such as reef islands and beaches (Perry et al. 2015b, 2017, Morgan \& Kench 2016).

Much of the current work on parrotfish functional roles is summarised in Bonaldo et al. (2014), but early work by Gygi (1975), Ogden (1977), Frydl \& Stearn (1978), and Scoffin et al. (1980) in the Caribbean highlighted the importance of parrotfish bioerosion. These early studies used estimates of daily gut throughput and sediment content in the gut to estimate bioerosion and sediment reworking rates (the ingestion, processing, and egestion of loose sediment on the reef). More direct estimates of parrotfish bioerosion, involving observations of daily feeding rates and measures of grazing scar dimensions, were then introduced by Bellwood (1995a) on the Great Barrier Reef and Bruggemann et al.
(1996) in the Caribbean. While more recent studies have quantified these processes for more species in different regions (e.g. Great Barrier Reef: Bellwood et al. 2003; Red Sea: Alwany et al. 2009; Hawaii: Ong \& Holland 2010), our understanding of the variability in these processes between species, sizes, and geographic locations remains very limited. There are $\sim 99$ recognised species of parrotfish worldwide, and $>70$ species are categorised into scraping or excavating feeding modes, many of which are geographically widespread (Choat et al. 2012). Yet direct estimates of parrotfish bioerosion rates are restricted to data from just 15 species from specific locations (Bellwood 1995a, Bruggemann et al. 1996, Bellwood et al. 2003, Alwany et al. 2009, Ong \& Holland 2010, Morgan \& Kench 2016). There is therefore little understanding of how bioerosion rates vary both among species, and among closely related species in different regions, with much of the current data restricted to the largest terminalphase males (see Bruggemann et al. 1996, Ong \& Holland 2010 for exceptions). In addition, studies examining how bioerosion rates differ between scraping and excavating species are sometimes contradictory (Bruggemann et al. 1996, Alwany et al. 2009, Ong \& Holland 2010). Some further studies contribute useful data on parrotfish bite rates and grazing scar dynamics in the context of algal grazing (such as Fox \& Bellwood 2007, Bonaldo \& Bellwood 2008, Lokrantz et al. 2008, Bejarano et al. 2013); however, even with this additional data, accessible datasets on parrotfish bioerosion rates are limited, given their diversity and geographic distribution.

The present study aimed to address a key geographic gap with respect to parrotfish bioerosion data by presenting rates, as well as associated feeding metrics, for 6 of the most common species present on Maldivian coral reefs. The central Indian Ocean remains an area where parrotfish populations are reported to be relatively healthy compared to other regions due to the lack of reef-based fishing pressure (McClanahan 2011) and are the most important bioeroding organisms in the region as a result (Perry et al. 2015b, 2017), yet region-specific rates are limited (but see Morgan \& Kench 2016 for data on 2 species). The species studied are representative of the range of sizes (including both initial and terminal life phases) and feeding modes of parrotfish found in the region. In addition, we consider how the bioerosion rate estimates from the present study compare with published data on the same, or closely related species in different regions; work that highlights the 
importance of collecting local rate data to inform bioerosion estimates.

\section{MATERIALS AND METHODS}

\section{Study area}

Data were collected during field seasons in early 2015 and 2016, primarily from an atoll edge reef platform site (Vavvaru, Lhaviyani Atoll) in the northerncentral Maldives (Fig. 1; 5²5' 5.0" N, 73²1' 14.0" E), and augmented with additional data on the same species collected in the southern Maldives (Kandahalagala and Maahutigalaa, Gaafu Dhaalu Atoll), also during the present study in early 2016. The Maldives experiences 2 monsoon periods, with winds from the westnorthwest during April-November (mean wind speed: $5.1 \mathrm{~m} \mathrm{~s}^{-1}$ ), and winds from the east-northeast during December-March (mean wind speed: $4.9 \mathrm{~m} \mathrm{~s}^{-1}$ ) (Kench \& Brander 2006). Daylight hours in the Maldives are fairly consistent throughout the year $\left(\sim 12 \mathrm{~h} \mathrm{~d}^{-1}\right)$, with $<30$ min variation over the year in Malé, Central Maldives, and sea surface temperatures varying by $<2{ }^{\circ} \mathrm{C}$ annually. Seasonal influences on parrotfish bite and bioerosion rates are therefore assumed to be minimal. The reef platforms at these sites are very shallow (typically $<2 \mathrm{~m}$ ), with coral cover extending down only to $\sim 8 \mathrm{~m}$ on outer platform slopes. While depth may influence parrotfish feeding (Bruggemann et al. 1996), it is thought to have limited influence in the present study due to the largely consistent depth of the platform.

\section{Species selection}

At the primary study site (Vavvaru Island), 15 species of parrotfish across 5 genera (Chlorurus spp., Scarus spp., Cetoscarus spp., Hipposcarus spp., and Calatomus spp.) were identified from a range of reef habitats across the reef platform. Based on preliminary measures of numerical dominance (Perry et al. 2017), and to ensure representation of the full range of sizes (including both initial and terminal life phases) and feeding modes (both scrapers and excavators), the following species were chosen for focussed study (species and total length, excluding filaments); excavators: Chlorurus sordidus (up to $\sim 40 \mathrm{~cm}$ ) and C. strongylocephalus (up to $70 \mathrm{~cm}$, but few over $\sim 60 \mathrm{~cm}$ ), and scrapers: Scarus frenatus (up to $\sim 50 \mathrm{~cm}$ ), $S$. niger (up to $\sim 45 \mathrm{~cm}$ ), $S$. psittacus (up to $\sim 30 \mathrm{~cm}$ ), and $S$. rubroviolaceus (up to $\sim 70 \mathrm{~cm}$, but few over $\sim 60 \mathrm{~cm}$ ). These species are widespread throughout the Indian Ocean, with closely related species found on reefs across the Indo-Pacific (Choat et al. 2012), making them ideal for regional comparisons of bioerosion rates.

\section{Bite rates and length of feeding day}

Previous work suggests that parrotfish feed for $\sim 80-90 \%$ of daylight hours (Bellwood 1995a). Observations of parrotfish bite rates were therefore carried out with coverage throughout the day between sunrise $(\sim 06: 20 \mathrm{~h})$ and sunset $(\sim 18: 20 \mathrm{~h})$, to ensure

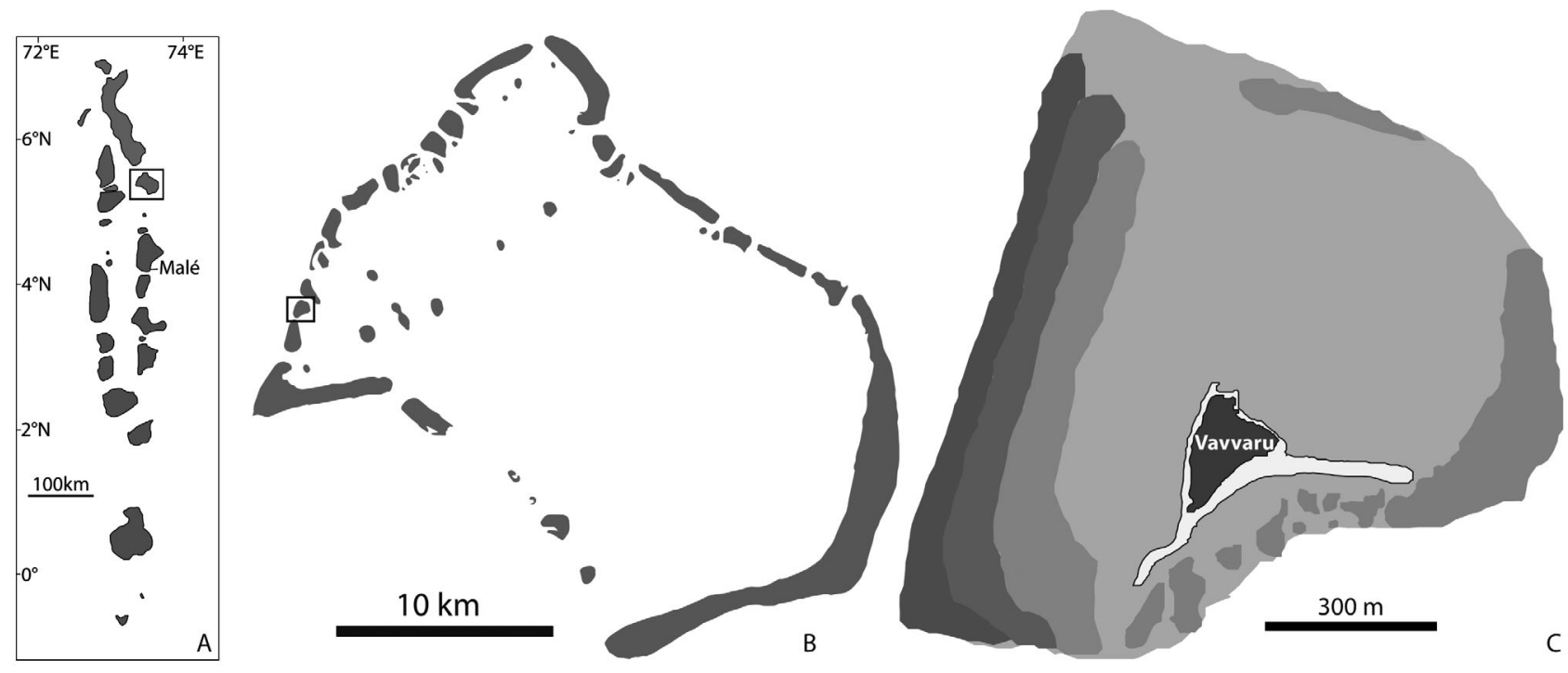

Fig. 1. (A) Lhaviyani atoll (square outline) in the Maldives, (B) location of Vavvaru Island (primary study site) on Lhaviyani atoll, and (C) Vavvaru platform, showing the location of Vavvaru Island. Shaded areas represent main reef zones where data collection took place 
capture of the start and end of feeding and to constrain for variation in bite rates throughout the day. Only initial-phase $S$. psittacus were observed, as terminal-phase males were rarely sighted. Individuals of a target study species, size, and life phase were chosen for observation on a first-seen basis to ensure random selection. Following standard protocols (e.g. Bellwood \& Choat 1990, Bellwood 1995a, Bruggemann et al. 1996, Ong \& Holland 2010, Morgan \& Kench 2016), fish were given $\sim 2$ min to become accustomed to the observer, during which time the species, life phase, size class (designated into 1 of the following size categories: $<15,16-30,31-45$, and $>46 \mathrm{~cm}$ ), and start time of the observation was recorded. A pilot study conducted prior to fieldwork (using PVC pipes underwater) revealed that the observer could consistently bin objects into $15 \mathrm{~cm}$ categories at a range of distances and angles relative to the object, and thus this was chosen instead of $10 \mathrm{~cm}$ bins, which had a higher frequency of errors. Only initial- and terminal-phase parrotfish were studied, as juveniles are thought to contribute extremely little to bioerosion (Bruggemann et al. 1996). Fish were then observed for 3-5 min, counting the total number of substrate bites by each species per unit of time, which was later converted to bites per minute (bpm). A LOESS regression with standard error was fitted to the data to help determine daily patterns. The length of the feeding day was determined from the time of day that the first bites by each species were observed until the point at which no further feeding was observed. Mean daily bite rates (bpm) were converted into total daily bites by multiplying by the length of the feeding day (in minutes). Observations taken before and after, and within the first and last $5 \%$ of the feeding day (if the observation appeared to be outside the feeding hours of the fish) were excluded.

\section{Proportion of bites producing grazing scars and grazing scar volumes}

Observations of the proportion of bites that produce grazing scars (PBS) and measurements of grazing scar volume were conducted for $C$. sordidus, $C$. strongylocephalus, S. frenatus, S. niger, and S. rubroviolaceus. Very small initial-phase $(<15 \mathrm{~cm}) C$. strongylocephalus were rarely sighted, and grazing scar volumes were thus assumed to be comparable to that of $<15 \mathrm{~cm} \mathrm{C}$. sordidus as the closest excavator relative (Choat et al. 2012). For S. psittacus, grazing scar volume metrics were assumed to be comparable to $S$. niger for similar size categories due to similarities in fish morphology, feeding mode, and feeding rate. Individuals of a target study species were again chosen on first-seen basis. To measure PBS, each fish was observed until a foray (a series of bites in quick succession), or a number of successive bites, could be clearly observed. Both the total number of bites observed and the number of observed new scars produced were recorded in order to determine PBS.

To measure the volume of parrotfish grazing scars, feeding was observed until the first observable grazing scar (such as those seen in Fig. 2) was produced. Where the location of the scar was both identified and accessible, the scar was measured. The length, width, and where possible, depth of scars was measured using Vernier callipers following conventional methods (Bellwood 1995a, Bruggemann et al. 1996, Bonaldo \& Bellwood 2008, 2009, Ong \& Holland 2010). The depths of the scars for large $C$. strongylocephalus could be measured fairly consistently. However, for most scrapers and smaller excavators, scar depth was extremely shallow $(\sim 0.1 \mathrm{~mm})$, and therefore often within the natural heterogeneity of the substrate. Depths of these scars therefore could not always be
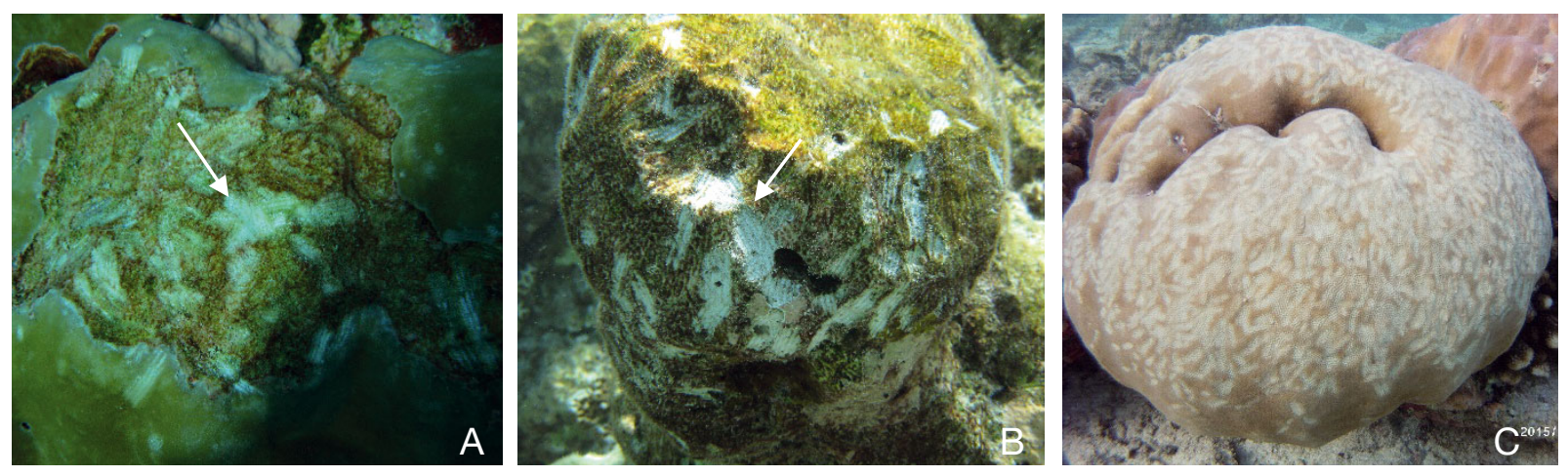

Fig. 2. Parrotfish grazing scars. (A) Scars (arrow) on dead coral substrates; (B) many of the larger scars (e.g. arrow) are likely to be from excavators such as Chlorurus strongylocephalus or Cetoscarus bicolor; and (C) parrotfish grazing scars are observed on some live corals, such as Porites spp. 
reliably measured, and thus, in these instances, a $0.1 \mathrm{~mm}$ depth assumption was used for excavators and large $(>30 \mathrm{~cm})$ S. rubroviolaceus (following assumptions made by Bellwood \& Choat 1990 and Bellwood et al. 1995a regarding scar size of excavators and large scrapers). For all other scrapers, as a function of the structural differences in jaw structure and resultant shallower 'scrapes' compared to excavators (Bellwood \& Choat 1990), a $0.05 \mathrm{~mm}$ depth was assumed. Grazing scars can occur as 1 mark, in which case the total length, width, and where possible, depth was measured. Where grazing scars occurred as 2 marks made by the upper and lower jaws, the length, width, and depth of both marks were measured. The volume of the grazing scar was assumed to be that of a rectangular prism and thus calculated as:

Bite volume $\left(\mathrm{cm}^{-3}\right)=\left(\mathrm{L}_{1} \times \mathrm{W}_{1} \times \mathrm{D}_{1}\right)+\left(\mathrm{L}_{2} \times \mathrm{W}_{2} \times \mathrm{D}_{2}\right)$

where $\mathrm{L}=$ length, $\mathrm{W}=$ width, $\mathrm{D}=$ depth, $1=$ first mark, and 2 = second mark (if present). This method may slightly overestimate grazing scar volume, but has been shown to be not significantly different to validated grazing scar measurements in the lab (Bellwood 1995a, Ong \& Holland 2010).

\section{Bioerosion and new sediment generation rates}

The bioerosion rate for an individual of each size class of each species of parrotfish was calculated as follows (adapted from Bruggemann et al. 1996, Ong \& Holland 2010):

Volume removed per day $\left(\mathrm{cm}^{3}\right.$ ind.$\left.^{-1} \mathrm{~d}^{-1}\right)=$ mean bites ind. $.^{-1} \mathrm{~d}^{-1} \times$ mean proportion of bites leaving scars $\times$ mean bite scar volume $\left(\mathrm{cm}^{3}\right)$

The overall standard error (SE) terms for this equation were calculated using an expanded 3-term version of Goodman's estimator (following Bellwood 1995a, Bruggemann et al. 1996, Ong \& Holland 2010):

$\mathrm{SE}_{(\overline{\mathrm{x}} \cdot \overline{\mathrm{y}} \cdot \overline{\mathrm{z}})}{ }^{2}=(\overline{\mathrm{x}} \cdot \overline{\mathrm{y}})^{2} \cdot \mathrm{SE}_{\mathrm{z}}{ }^{2}+(\overline{\mathrm{x}} \cdot \overline{\mathrm{z}})^{2} \cdot \mathrm{SE}_{\mathrm{y}}{ }^{2}+(\overline{\mathrm{y}} \cdot \overline{\mathrm{z}})^{2} \cdot \mathrm{SE}_{\mathrm{x}}{ }^{2}$ $+(\overline{\mathrm{x}})^{2} \cdot \mathrm{SE}_{\mathrm{y}}^{2} \cdot \mathrm{SE}_{\mathrm{z}}^{2}+(\overline{\mathrm{y}})^{2} \cdot \mathrm{SE}_{\mathrm{x}}^{2} \cdot \mathrm{SE}_{\mathrm{z}}^{2}+(\overline{\mathrm{z}})^{2} \cdot \mathrm{SE}_{\mathrm{x}}{ }^{2} \cdot \mathrm{SE}_{\mathrm{y}}{ }^{2}$ $+\mathrm{SE}_{\mathrm{x}}^{2} \cdot \mathrm{SE}_{\mathrm{y}}^{2} \cdot \mathrm{SE}_{\mathrm{z}}^{2}$

where $\overline{\mathrm{x}}=$ mean bites per day, $\overline{\mathrm{y}}=$ mean proportion of bites leaving scars, and $\overline{\mathrm{z}}=$ mean bite volume.

Resultant annual bioerosion rates per individual fish were then calculated by multiplying the volume removed per day by the substrate density (taken as $1.5 \mathrm{~g} \mathrm{~cm}^{-3}$ as the average of locally measured rates;
Morgan \& Kench 2012), and by the number of days in a year:

Bioerosion rate $\left(\mathrm{kg}\right.$ ind. $\left.{ }^{-1} \mathrm{yr}^{-1}\right)=$ volume removed per day $\left(\mathrm{cm}^{3}\right.$ ind. $\left.{ }^{-1} \mathrm{~d}^{-1}\right) \times 0.0015 \mathrm{~kg} \mathrm{~cm}^{-3} \times 365 \mathrm{~d} \mathrm{yr}^{-1}$

\section{Statistical analysis}

Statistical analyses were conducted in $\mathrm{R}$ v.3.3.2. One-way ANOVA, Welch 1-way test, or KruskalWallis tests (depending on what assumptions the data meet) were used to test for differences in bite rate, PBS, and scar volume among species and size classes. Data for initial- and terminal-phase parrotfish within each species were pooled and presented here as a function of size class (see Table 1). This was due to the smaller 2 size classes $(<15 \mathrm{~cm}$ and $16-$ $30 \mathrm{~cm}$ ) being made up primarily by initial-phase parrotfish, while the larger 2 size classes $(31-45 \mathrm{~cm}$ and $>46 \mathrm{~cm}$ ) were made up primarily of terminal-phase males.

\section{RESULTS}

\section{Bite rates and length of feeding day}

The length of the feeding day was consistent across all 6 species studied. Feeding typically commenced between 06:30 and 07:00 h, about 10-40 min after sunrise, and had ceased by 18:00 h, about $20 \mathrm{~min}$ before sunset (11-11.5 h feeding day; $11 \mathrm{~h}$ was used in calculations). All species appeared to exhibit a bimodal pattern (i.e. 2 peaks) in their feeding activity, albeit subtle in some species, with a first peak typically occurring around 11:00 h, and a second, often larger peak between 15:00 and 16:00 h (Fig. 3). Bite rate differed significantly among species $\left(F_{5,259}=\right.$ $33.184, \mathrm{p}<0.001$, Table 1), with pairwise $t$-test comparisons revealing significant differences $(p<0.05)$ between all pairs of species, with the exceptions of Chlorurus strongylocephalus and Scarus rubroviolaceus, and S. niger and S. psittacus. These differences in bite rate appeared to occur primarily among smaller individuals, and resulted in considerable differences in numbers of total daily bites (Table. 2). Mean bite rate varied from $7.88 \pm 0.63 \mathrm{bpm}$ for $C$. strongylocephalus to $23.65 \pm 1.42 \mathrm{bpm}$ for $S$. niger. No consistent relationship was apparent between fish size and bite rate (Table 1). $S$. frenatus and $S$. niger both showed a significant increase in bite rate 

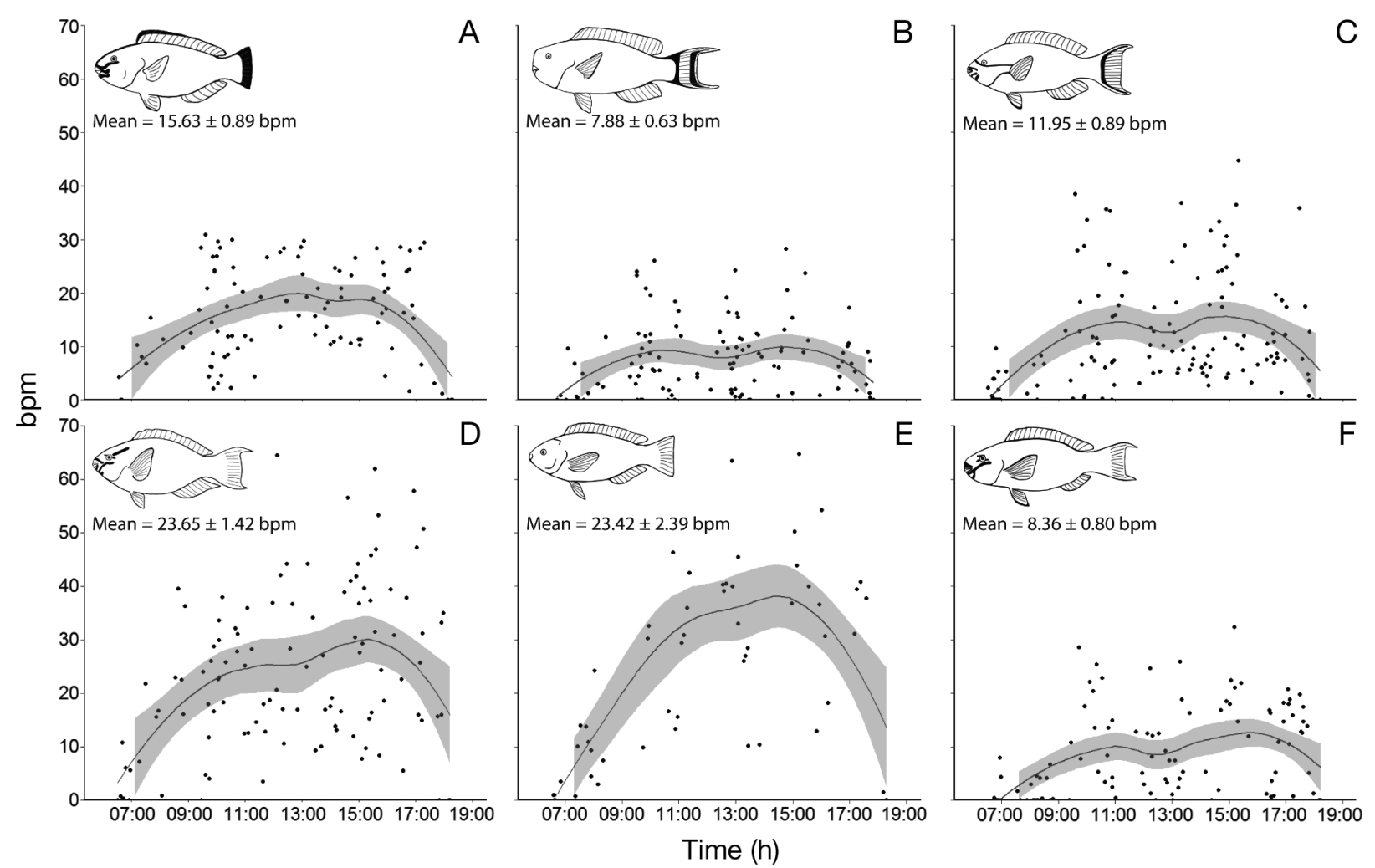

Fig. 3. Daily bite rate patterns (bites per minute; bpm), including the full range of sizes and initial and terminal life phases for excavators: (A) Chlorurus sordidus and (B) C. strongylocephalus; and scrapers: (C) Scarus frenatus, (D) S. niger, (E) S. psittacus, and (F) S. rubroviolaceus. A LOESS curve is fitted to show the general trend in bite rate over the course of the day. The shaded area represents standard error

with fish size $\left(F_{2,84}=5, \mathrm{p}<0.01\right.$ and $F_{2,110}=9.6, \mathrm{p}<$ 0.01 respectively).

\section{Proportion of bites producing scars and mass removed per grazing scar}

With the exception of large $(>46 \mathrm{~cm})$ C. strongylocephalus, not every bite produced an observable grazing scar (Fig. 4). PBS increased significantly ( $\mathrm{p}<$ $0.05)$, although not always consistently, with fish size in all species except $S$. niger $(p>0.05)$. Only around a quarter of bites by fish in the smaller size classes of most species $(<15 \mathrm{~cm})$ produced scars, and at this size there were no significant differences between species $\left(H_{4}=7, \mathrm{p}=0.13\right)$. However, higher PBS (ranging between 0.5, and almost 1.0, depending on species) were observed in the larger size classes, and statistically significant differences were observed between species (Tables $3 \& 4$ ). The mass of framework substrate removed per grazing scar increased consistently with fish size in all species studied, and was significant $(p<0.05)$ in all species (Fig. 5, Table 4). Excavators eroded markedly more material per grazing scar com- pared to scrapers, and consistently eroded more material compared to scrapers for the same size class (Table 5). For example, C. strongylocephalus eroded up to $0.26 \pm 0.08 \mathrm{~g}$ of substrate per bite for individuals over $45 \mathrm{~cm}$, compared to $0.002 \pm 9.13 \times 10^{-4} \mathrm{~g}$ per bite by comparably sized $S$. rubroviolaceus (a scraper). No significant differences were found between scraping species at any size class (Table 5).

\section{Rates of bioerosion}

Estimates of annual bioerosion rates $\left(\mathrm{kg}\right.$ ind..$\left.^{-1} \mathrm{yr}^{-1}\right)$ revealed considerable variation among species and between feeding modes (Fig. 6, Table 6). Excavating parrotfish erode considerably more framework material compared to scrapers in all size classes. C. strongylocephalus had the highest bioerosion rate among the excavators, with the largest individuals $(>45 \mathrm{~cm})$ eroding $462 \pm 128 \mathrm{~kg}$ ind. ${ }^{-1} \mathrm{yr}^{-1}$. By comparison, $S$. rubroviolaceus had the highest bioerosion rate among the scrapers, with the largest individuals $(>45 \mathrm{~cm})$ calculated to erode $\sim 3.6 \pm 1.4 \mathrm{~kg}$ ind..$^{-1} \mathrm{yr}^{-1}$. In all species, rates of bioerosion increased with body size. 
Table 1. Mean bites per minute $( \pm \mathrm{SE})$ for each size class of the 6 study species. Within species $=$ pairwise statistical differences of size classes within the same species. Values with the same letter are not statistically significantly different. Pairwise comp. shows where no significant differences exist between species at the same size category. N/A = not applicable because the species does not occur in the size range at the study site. C.s $=$ Chlorurus sordidus, C.st $=$ C. strongylocephalus, S.f $=$ Scarus frenatus, $\mathrm{S} . \mathrm{n}=$ S. niger, S. p = S. psittacus, S.r $=$ S. rubroviolaceus

\begin{tabular}{|ccccccc|}
\hline \multirow{2}{*}{ Species } & Size & N & Mean & SE & Within & Pairwise \\
& $(\mathrm{cm})$ & & & & & species \\
& & & & & \\
C.s & $<15$ & 26 & 18.25231 & 2.046745 & A & S.n, S.p \\
& $16-30$ & 34 & 17.14000 & 1.307449 & A & S.f, S.n \\
& $31-45$ & 32 & 16.90656 & 1.155723 & A & S.f \\
& $>46$ & N/A & N/A & N/A & & \\
C.st & $<15$ & 4 & 6.965000 & 0.9860063 & A & S.f, S.r \\
& $16-30$ & 21 & 10.296667 & 1.3327757 & A & S.f, S.r \\
& $31-45$ & 37 & 7.262162 & 1.0909511 & A & \\
& $>46$ & 39 & 9.072308 & 1.2161017 & A & S.r \\
S.f & $<15$ & 19 & 8.978421 & 1.453600 & A & C.st, S.r \\
& $16-30$ & 43 & 13.984419 & 1.471914 & B & C.s, C.st \\
& $31-45$ & 49 & 15.493061 & 1.672830 & B & C.s, S.r \\
& $>46$ & N/A & N/A & N/A & & \\
S.n & $<15$ & 20 & 23.17300 & 3.502616 & A & C.s, S.p \\
& $16-30$ & 36 & 21.81278 & 2.131744 & A & C.s \\
& $31-45$ & 41 & 31.53268 & 2.007945 & B & \\
& $>46$ & N/A & N/A & N/A & & \\
S.p & $<15$ & 34 & 29.18500 & 2.758080 & A & C.s, S.n \\
& $16-30$ & 11 & 32.42636 & 4.822018 & A & \\
& $31-45$ & N/A & N/A & N/A & & \\
& $>46$ & N/A & N/A & N/A & & \\
S.r & $<15$ & 6 & 5.425000 & 2.468292 & ABC & C.st, S.f \\
& $16-30$ & 23 & 6.756522 & 1.699362 & A & C.st \\
& $31-45$ & 32 & 13.936875 & 1.456668 & B & S.f \\
& $>46$ & 25 & 7.492800 & 1.553906 & AC & C.st \\
\hline
\end{tabular}

\section{DISCUSSION}

Accurately measuring and understanding the factors that control parrotfish bioerosion rates are essential, given the importance of this process to reef carbonate budgets and to sand supply rates that influence the maintenance of both reefs and reef islands (Perry et al. 2014, 2015a, Morgan \& Kench 2016). The present study contributes to this important area of research by significantly extending the available dataset for parrotfish bioerosion rates in the central Indian Ocean. New size-specific estimates for previously studied 'excavator' species are presented, along with data for 4 previously unstudied 'scraping' species in this region. The results of the present study show similarly high functional variability between species, sizes, and feeding modes of parrotfish, as demonstrated in studies from other geographic locations (Bruggemann et al. 1996, Alwany et al. 2009).
Table 2. Total daily bites for each size class of the 6 study species. N/A = not applicable because the species does not occur in this size class at the study site. See Table 1 for species abbreviations

\begin{tabular}{|c|c|c|c|c|}
\hline Species & Size $(\mathrm{cm})$ & $\mathrm{N}$ & Mean & $\mathrm{SE}$ \\
\hline C.s & $\begin{array}{c}<15 \\
16-30 \\
31-45 \\
>46\end{array}$ & $\begin{array}{c}26 \\
34 \\
32 \\
\text { N/A }\end{array}$ & $\begin{array}{c}12045.00 \\
11312.40 \\
11160.60 \\
\text { N/A }\end{array}$ & $\begin{array}{c}1350.85 \\
862.92 \\
762.78 \\
\text { N/A }\end{array}$ \\
\hline C.st & $\begin{array}{c}<15 \\
16-30 \\
31-45 \\
>46\end{array}$ & $\begin{array}{c}4 \\
21 \\
37 \\
39\end{array}$ & $\begin{array}{l}4596.90 \\
6798.00 \\
4791.60 \\
5986.20\end{array}$ & $\begin{array}{l}650.76 \\
879.63 \\
720.03 \\
802.63\end{array}$ \\
\hline S.f & $\begin{array}{c}<15 \\
16-30 \\
31-45 \\
>46\end{array}$ & $\begin{array}{c}19 \\
43 \\
49 \\
\text { N/A }\end{array}$ & $\begin{array}{c}5925.76 \\
9226.80 \\
10223.40 \\
\text { N/A }\end{array}$ & $\begin{array}{r}959.38 \\
971.46 \\
1104.07 \\
\text { N/A }\end{array}$ \\
\hline S.n & $\begin{array}{c}<15 \\
16-30 \\
31-45 \\
>46\end{array}$ & $\begin{array}{c}20 \\
36 \\
41 \\
\text { N/A }\end{array}$ & $\begin{array}{c}15292.20 \\
14394.60 \\
20811.57 \\
\text { N/A }\end{array}$ & $\begin{array}{c}2311.73 \\
1406.95 \\
1325.24 \\
\text { N/A }\end{array}$ \\
\hline S.p & $\begin{array}{c}<15 \\
16-30 \\
31-45 \\
>46\end{array}$ & $\begin{array}{c}34 \\
11 \\
\text { N/A } \\
\text { N/A }\end{array}$ & $\begin{array}{c}19262.10 \\
21401.40 \\
\text { N/A } \\
\text { N/A }\end{array}$ & $\begin{array}{c}1820.33 \\
3182.53 \\
\text { N/A } \\
\text { N/A }\end{array}$ \\
\hline S.r & $\begin{array}{c}<15 \\
16-30 \\
31-45 \\
>46\end{array}$ & $\begin{array}{c}6 \\
23 \\
32 \\
25\end{array}$ & $\begin{array}{l}3583.80 \\
4461.60 \\
9193.80 \\
4943.40\end{array}$ & $\begin{array}{r}1629.07 \\
1121.58 \\
961.40 \\
1025.58\end{array}$ \\
\hline
\end{tabular}

However, despite broad similarities to the findings in these earlier studies (Bellwood 1995a, Bruggemann et al. 1996, Bellwood et al. 2003, Alwany et al. 2009, Ong \& Holland 2010, Morgan \& Kench 2016), our data suggest surprisingly high variability in bioerosion rates when comparing rates for the same species (or species within the same clade) between regions. These differences could suggest (1) that local environmental conditions are a major control on parrotfish bioerosion rates, and/or (2) that challenges associated with directly measuring some key variables, especially those linked to the grazing scars themselves, may be responsible for exaggerating some observed variability.

\section{Maldivian parrotfish bioerosion rates}

Three key measures are required to calculate parrotfish bioerosion rate: bite rate, the proportion of bites that produce scars, and grazing scar volume. Each of these measures showed high variability among species, and with size and feeding modes of parrotfish, resulting in markedly different bioero- 

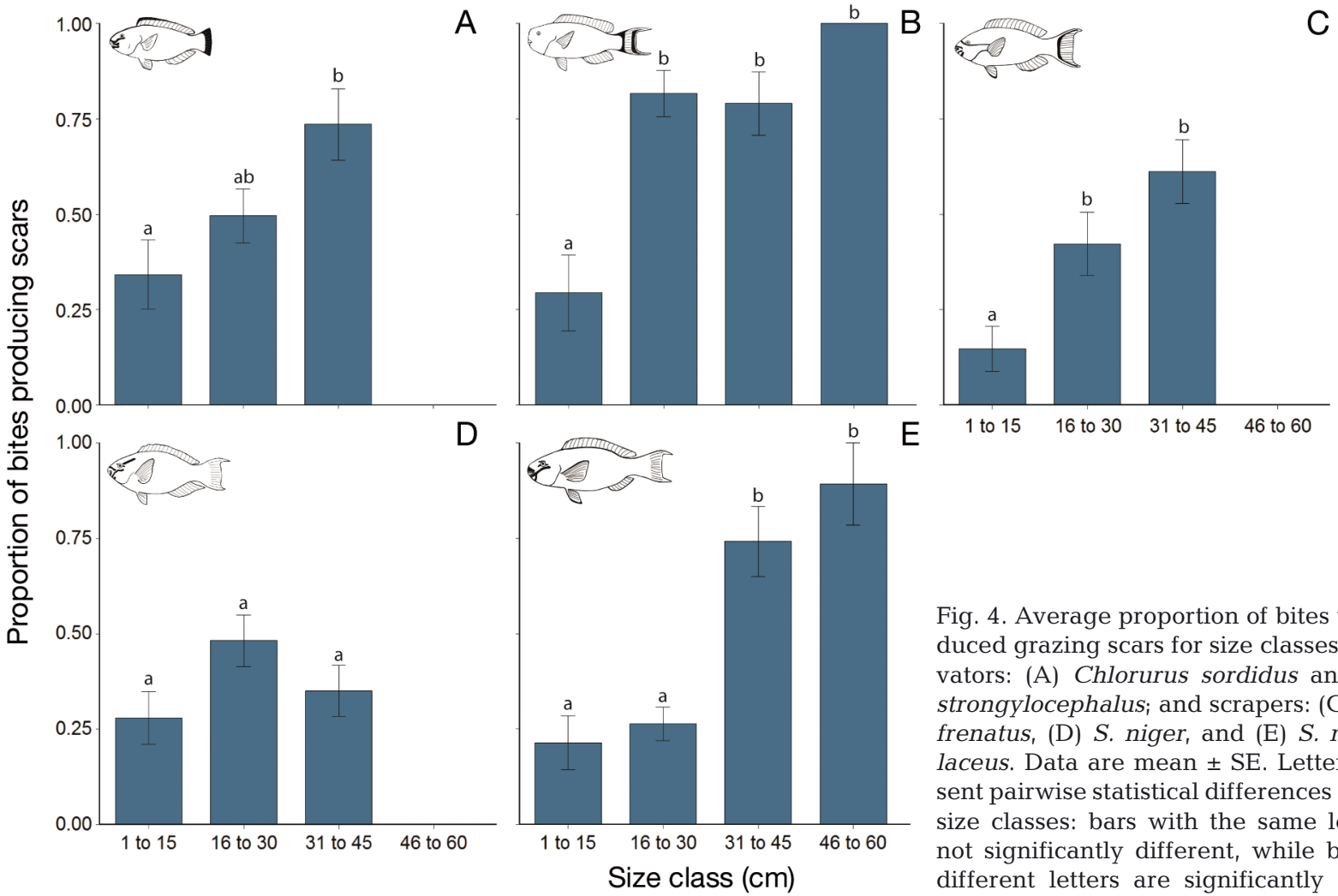

Fig. 4. Average proportion of bites that produced grazing scars for size classes of excavators: (A) Chlorurus sordidus and (B) $C$. strongylocephalus; and scrapers: (C) Scarus frenatus, (D) S. niger, and (E) S. rubroviolaceus. Data are mean $\pm \mathrm{SE}$. Letters represent pairwise statistical differences between size classes: bars with the same letter are not significantly different, while bars with different letters are significantly different

Table 3. Average proportion of bites that produce grazing scars by species and size class. Pairwise comparisons show where no significant difference exists between species of the same size category. N/A = not applicable because the species does not occur in this size class at the study site. See Table 1 for species abbreviations

\begin{tabular}{|c|c|c|c|c|c|}
\hline Species & $\begin{array}{l}\text { Size } \\
(\mathrm{cm})\end{array}$ & $\mathrm{N}$ & Mean & $\mathrm{SE}$ & $\begin{array}{l}\text { Pairwise } \\
\text { comp. }\end{array}$ \\
\hline C.s & $\begin{array}{c}<15 \\
16-30 \\
31-45 \\
>46\end{array}$ & $\begin{array}{c}16 \\
24 \\
10 \\
\text { N/A }\end{array}$ & $\begin{array}{l}0.341875 \\
0.496250 \\
0.736000 \\
\quad \text { N/A }\end{array}$ & $\begin{array}{c}0.09032450 \\
0.07077678 \\
0.09373959 \\
\text { N/A }\end{array}$ & $\begin{array}{c}\text { C.st, S.f, S.n, S.r } \\
\text { S.f, S.n } \\
\text { C.st, S.f, S.r }\end{array}$ \\
\hline C.st & $\begin{array}{c}<15 \\
16-30 \\
31-45 \\
>46\end{array}$ & $\begin{array}{c}5 \\
22 \\
16 \\
10\end{array}$ & $\begin{array}{l}0.2940000 \\
0.8172727 \\
0.7906250 \\
1.0000000\end{array}$ & $\begin{array}{l}0.09907573 \\
0.06042484 \\
0.08269154 \\
0.00000000\end{array}$ & $\begin{array}{l}\text { C.s, S.f, S.r } \\
\text { S.r }\end{array}$ \\
\hline S.f & $\begin{array}{c}<15 \\
16-30 \\
31-45 \\
>46\end{array}$ & $\begin{array}{c}19 \\
24 \\
11 \\
\text { N/A }\end{array}$ & $\begin{array}{c}0.1473684 \\
0.4229167 \\
0.6118182 \\
\quad \text { N/A }\end{array}$ & $\begin{array}{c}0.05954428 \\
0.08284235 \\
0.08350088 \\
\text { N/A }\end{array}$ & $\begin{array}{c}\text { C.s, C.st, S.n, S.r } \\
\text { C.s, S.n, S.r } \\
\text { C.s, C.st, S.r }\end{array}$ \\
\hline S.n & $\begin{array}{c}<15 \\
16-30 \\
31-45 \\
>46\end{array}$ & $\begin{array}{c}14 \\
26 \\
15 \\
\text { N/A }\end{array}$ & $\begin{array}{c}0.2800000 \\
0.4823077 \\
0.3513333 \\
\text { N/A }\end{array}$ & $\begin{array}{c}0.06917091 \\
0.06720647 \\
0.06673235 \\
\text { N/A }\end{array}$ & $\begin{array}{l}\text { C.s, C.st, S.f, S.r } \\
\text { C.s, S.f, S.r }\end{array}$ \\
\hline S.r & $\begin{array}{c}<15 \\
16-30 \\
31-45 \\
>46\end{array}$ & $\begin{array}{c}14 \\
9 \\
10 \\
7\end{array}$ & $\begin{array}{l}0.2142857 \\
0.2644444 \\
0.7420000 \\
0.8928571\end{array}$ & $\begin{array}{l}0.07052172 \\
0.04359253 \\
0.09163696 \\
0.10714286\end{array}$ & $\begin{array}{c}\text { C.s, C.st, S.f, s.n } \\
\text { S.f, S.n } \\
\text { C.s, C.st, S.f } \\
\text { C.st }\end{array}$ \\
\hline
\end{tabular}

sion rates. The feeding patterns we observed were, however, comparable across all species studied. Bite rate in all species gradually increased throughout the morning, peaking in late morning and midafternoon, and halting abruptly $\sim 20$ min before sunset. Parrotfish feeding patterns were once thought to correlate with rates of algal photosynthesis, and resultant nutritional quality of the algae on which parrotfish were assumed to feed (Afeworki et al. 2013). This nutritional quality hypothesis may still stand, despite recent evidence that parrotfish are likely to be microphages, targeting protein-rich cyanobacteria living on and within the reef framework (Clements et al. 2016), as cyanobacteria are also photosynthetic. The results from our study, however, differ to those previously published (e.g. Bellwood 1995a, Bruggemann et al. 1994b, Bonaldo et al. 2006, Ong \& Holland 2010) by having a consistent bimodal pattern. An initial peak occurs in all (albeit subtle in some; our Fig. 3) species at $\sim 11: 00 \mathrm{~h}$, and a second, often slightly larger peak between 15:00 and 16:00 $\mathrm{h}$. We hypothesise that this may be due to the process of photoinhibition in cyanobacteria following high light intensity, which may cause a dip, or halted increase in nutritional quality (Long et al. 1994, Zemke-White et al. 2002, Takahashi \& Murata 2008), and which may be especially pro- 
Table 4. Summary of statistical tests for bite metrics

\begin{tabular}{|c|c|c|c|}
\hline \multicolumn{4}{|l|}{ Bite rate } \\
\hline Welch 1-way test & $F$ & df & $\mathbf{p}$ \\
\hline Between species (all data) & 33.2 & 5,258 & $<0.01$ \\
\hline Between species $(<15 \mathrm{~cm})$ & 9.1 & 5,33 & $<0.01$ \\
\hline Between species $(16-30 \mathrm{~cm})$ & 10.9 & 5,61 & $<0.01$ \\
\hline Between species $(31-45 \mathrm{~cm})$ & 31.8 & 4,102 & $<0.01$ \\
\hline Chlorurus sordidus (between sizes) & 0.7 & 2,64 & $>0.05$ \\
\hline Scarus frenatus (between sizes) & 5.1 & 2,84 & $<0.01$ \\
\hline \multicolumn{4}{|l|}{ 1-way ANOVA } \\
\hline C. strongylocephalus (between sizes) & 0.7 & 3,111 & $>0.05$ \\
\hline S. niger (between sizes) & 9.6 & 2,110 & $<0.01$ \\
\hline S. rubroviolaceus (between sizes) & 6.6 & 3,105 & $<0.01$ \\
\hline$t$-test & $t$ & df & $\mathbf{p}$ \\
\hline Species (>46 cm) & 1.7 & 70 & $>0.05$ \\
\hline S. psittacus (between sizes) & -2.0 & 17 & $>0.05$ \\
\hline \multicolumn{4}{|l|}{ Proportion of bites producing scars } \\
\hline Kruskal-Wallis & $\boldsymbol{H}$ & df & $\mathbf{p}$ \\
\hline C. sordidus (between sizes) & 10.3 & 3 & $<0.05$ \\
\hline C. strongylocephalus (between sizes) & 16.4 & 3 & $<0.001$ \\
\hline S. frenatus (between sizes) & 16.6 & 3 & $<0.001$ \\
\hline$S$. niger (between sizes) & 6.8 & 3 & $>0.05$ \\
\hline S. rubroviolaceus (between sizes) & 23.2 & 3 & $<0.001$ \\
\hline Between species $(<15 \mathrm{~cm})$ & 7.1 & 4 & $>0.05$ \\
\hline Between species $(16-30 \mathrm{~cm})$ & 21.2 & 4 & $<0.001$ \\
\hline Between species $(31-45 \mathrm{~cm})$ & 16.3 & 4 & $<0.01$ \\
\hline Wilcoxon & $\boldsymbol{W}$ & & $\mathbf{p}$ \\
\hline Between species $(>46 \mathrm{~cm})$ & 40 & & $>0.05$ \\
\hline \multicolumn{4}{|l|}{ Grazing scar volumes } \\
\hline Kruskal-Wallis & $\boldsymbol{H}$ & df & $\mathbf{p}$ \\
\hline C. sordidus (between sizes) & 19.8 & 3 & $<0.001$ \\
\hline C. strongylocephalus (between sizes) & 13.9 & 3 & $<0.01$ \\
\hline S. frenatus (between sizes & 12.2 & 3 & $<0.01$ \\
\hline$S$. niger (between sizes) & 17.9 & 3 & $<0.001$ \\
\hline S. rubroviolaceus (between sizes) & 21.2 & 3 & $<0.001$ \\
\hline Between species $(<15 \mathrm{~cm})$ & 15.1 & 4 & $<0.01$ \\
\hline Between species $(16-30 \mathrm{~cm})$ & 38.4 & 4 & $<0.001$ \\
\hline Between species $(31-45 \mathrm{~cm})$ & 31.4 & 4 & $<0.001$ \\
\hline Wilcoxon & $\boldsymbol{W}$ & & $\mathbf{p}$ \\
\hline Between species $(>46 \mathrm{~cm}$ ) & 79 & & $<0.01$ \\
\hline
\end{tabular}

nounced in extremely shallow environments such as the reef platforms studied here (mostly $<2 \mathrm{~m}$ ). This phenomenon warrants further investigation to examine the significance and causes.

While the feeding patterns observed in the present study are in broad agreement with much of the literature (e.g. Bruggemann et al. 1996, Ong \& Holland 2010, Morgan \& Kench 2016), the major difference observed here is that we observe no significant decrease in bite rate with fish size. While this is not the first study to show that this trend is not always present (Bonaldo \& Bellwood 2008), it is the first, to our knowledge, that shows an increase in bite rate with fish size in 2 species (Scarus frenatus and $S$. niger). This was unexpected given that feeding rates typically decline with body mass as a result of lower energetic requirements per unit mass in larger fish. It is unclear whether bite rate and feeding rate are tightly coupled, and whether this higher bite rate equates to a higher intake of food. Regardless, these higher bite rates did not correspond to higher bioerosion rates (Figs. $3 \& 6$ ). In fact, the species with the lowest bite rates had the highest bioerosion rates for their respective feeding modes (Chlorurus strongylocephalus for the excavators and S. rubroviolaceus for the scrapers). This is explained by the relatively larger scar volumes produced in these species compared to those that have faster bite rates. The volume of grazing scars appears to be the key variable in determining observed patterns of bioerosion, and the only variable to increase consistently with fish size (Fig. 5). The proportion of bites producing observable scars is also a contributing factor, with larger individuals, especially larger excavators, typically having a higher proportion of bites producing scars (Fig. 4).

Large (>45 cm) excavators (particularly C. strongylocephalus) had especially high bioerosion rates, and can erode up to $462 \pm 128 \mathrm{CaCO}_{3} \mathrm{~kg}$ ind. ${ }^{-1} \mathrm{yr}^{-1}$. This rate is over 130 times higher than that for comparably sized scraping species (e.g. S. rubroviolaceus). Bioerosion rate also increased significantly with fish size, a trend that is especially pronounced in excavators. While it is no surprise that larger individuals of a species erode more substrate compared to smaller individuals, an ability to quantify how much more 'large' parrotfish erode is critically important to consider from a reef management perspective (Birkeland \& Dayton 2005). In some regions, parrotfish are a target fishery and a source of protein for local communities (e.g. McClanahan 1994, Aswani \& Sabetian 2010, Bellwood et al. 2012, Taylor et al. 2015), and in these cases, larger individuals are commonly targeted (Bellwood et al. 2012), thereby reducing the local mean size of parrotfish (Taylor et al. 2015). Based on our results, the implications of targeted fishing efforts for reef bioerosion in a system such as this (that supports an abundance of large parrotfish and especially $>45 \mathrm{~cm}$ excavators) is likely to be profound. Specifically, the loss of larger individuals may result in a considerable reduction of total bioerosion by the wider parrotfish population, with implications for coral recruitment success (Bellwood et al. 2004, 

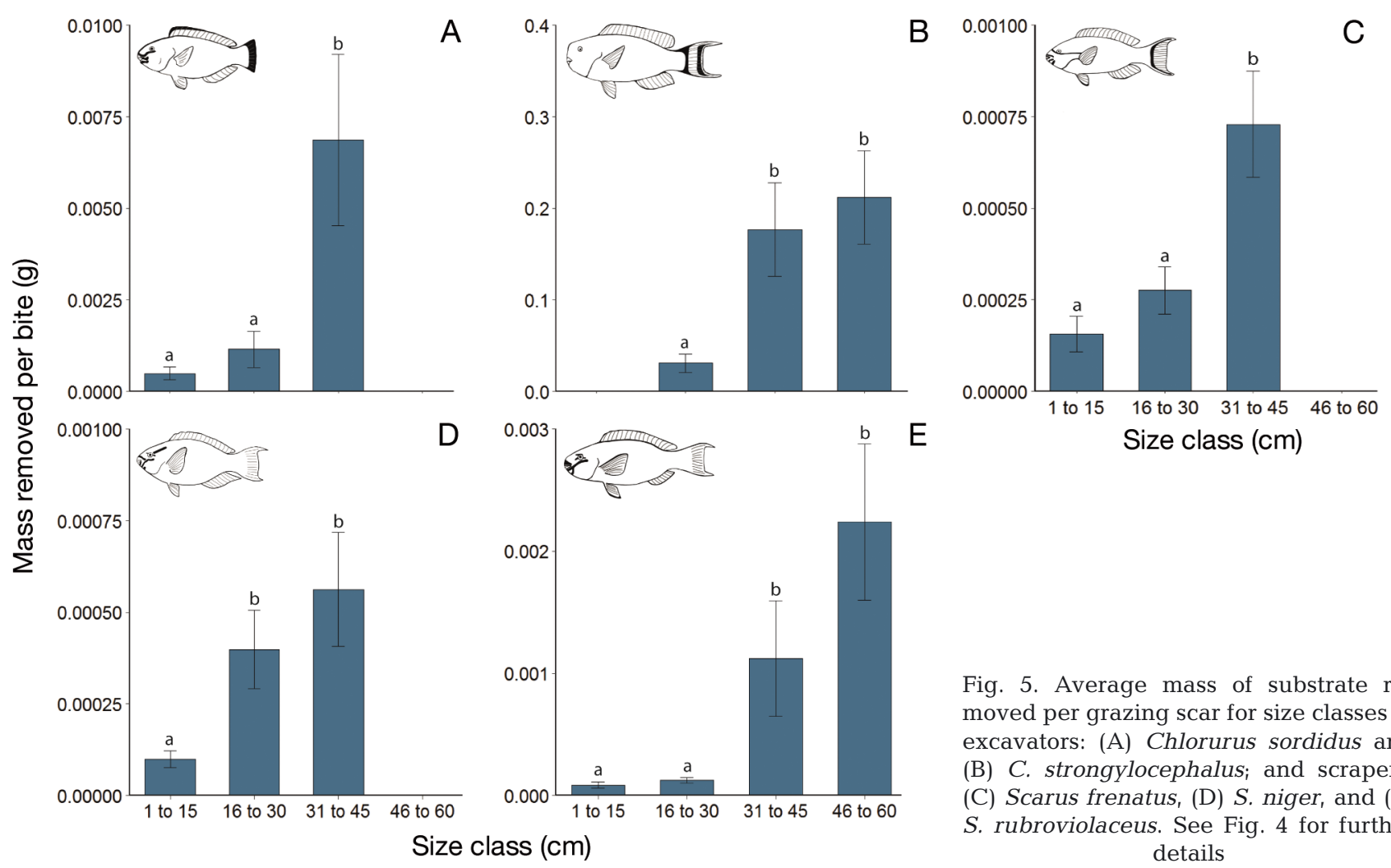

Fig. 5. Average mass of substrate removed per grazing scar for size classes of excavators: (A) Chlorurus sordidus and (B) C. strongylocephalus; and scrapers: (C) Scarus frenatus, (D) S. niger, and (E) $S$. rubroviolaceus. See Fig. 4 for further details

Mumby 2006), shifts in carbonate budget states (Perry et al. 2014), and modified rates and grain sizes of sediment supply to reefs and reef islands (Perry et al. 2015a). Past studies would suggest that fishing pressure on large excavators results in an increase in biomass of smaller excavators (Bellwood et al. 2012). The question remains whether this increase in smaller parrotfish would be sufficient to compensate for the loss of larger individuals.

\section{Regional comparisons}

Data on parrotfish bioerosion rates now spans the Red Sea, Great Barrier Reef, Caribbean, north-central Pacific, and the central Indian Ocean. In the Indo-Pacific, some species of parrotfish are widespread, or closely related species (within the same clade) exist in adjacent regions (Choat et al. 2012). The available evidence suggests that very high variability exists between regions for the same species, or clade (Bonaldo et al. 2014). For example, bioerosion rates for adults in
Table 5. Average mass removed by grazing scars by species and size class. Pairwise comparisons show where no significant difference $(p>0.05)$ exists between species of the same size category. See Table 2 for species abbreviations

\begin{tabular}{|c|c|c|c|c|c|}
\hline Species & $\begin{array}{l}\text { Size } \\
(\mathrm{cm})\end{array}$ & $\mathrm{N}$ & Mean & $\mathrm{SE}$ & $\begin{array}{l}\text { Pairwise } \\
\text { comp. }\end{array}$ \\
\hline C.s & $\begin{array}{c}<15 \\
16-30 \\
31-45 \\
>46\end{array}$ & $\begin{array}{c}13 \\
22 \\
7 \\
\text { N/A }\end{array}$ & $\begin{array}{c}0.0004932692 \\
0.0011488636 \\
0.0068678571 \\
\text { N/A }\end{array}$ & $\begin{array}{c}0.0001698334 \\
0.0004988169 \\
0.0023380313 \\
\text { N/A }\end{array}$ & S.n \\
\hline C.st & $\begin{array}{c}<15 \\
16-30 \\
31-45 \\
>46\end{array}$ & $\begin{array}{c}\text { N/A } \\
19 \\
12 \\
12\end{array}$ & $\begin{array}{c}\mathrm{N} / \mathrm{A} \\
0.03079934 \\
0.17688750 \\
0.21175625\end{array}$ & $\begin{array}{c}\text { N/A } \\
0.01012978 \\
0.05117699 \\
0.05100581\end{array}$ & \\
\hline S.f & $\begin{array}{c}<15 \\
16-30 \\
31-45 \\
>46\end{array}$ & $\begin{array}{c}6 \\
11 \\
10 \\
\text { N/A }\end{array}$ & $\begin{array}{c}0.0001562500 \\
0.0002761364 \\
0.0007293750 \\
\text { N/A }\end{array}$ & $\begin{array}{c}4.881406 \times 10^{-5} \\
6.436324 \times 10^{-5} \\
1.450337 \times 10^{-4} \\
\text { N/A }\end{array}$ & $\begin{array}{l}\text { S.n, S.r } \\
\text { S.n, S.r } \\
\text { S.n, S.r }\end{array}$ \\
\hline S.n & $\begin{array}{c}<15 \\
16-30 \\
31-45 \\
>46\end{array}$ & $\begin{array}{c}14 \\
12 \\
9 \\
\text { N/A }\end{array}$ & $\begin{array}{c}9.910714 \times 10^{-5} \\
3.984375 \times 10^{-4} \\
5.625000 \times 10^{-4} \\
\text { N/A }\end{array}$ & $\begin{array}{c}0.0000226189 \\
0.0001070937 \\
0.0001559998 \\
\text { N/A }\end{array}$ & $\begin{array}{l}\text { C.s, S.f, S.r } \\
\text { S.f, S.r } \\
\text { S.f, S.r }\end{array}$ \\
\hline S.r & $\begin{array}{c}<15 \\
16-30 \\
31-45 \\
>46\end{array}$ & $\begin{array}{c}4 \\
7 \\
12 \\
7\end{array}$ & $\begin{array}{l}0.0000843750 \\
0.0001232143 \\
0.0011218750 \\
0.0022392857\end{array}$ & $\begin{array}{l}2.359323 \times 10^{-5} \\
2.120418 \times 10^{-5} \\
4.731376 \times 10^{-4} \\
6.387967 \times 10^{-4}\end{array}$ & $\begin{array}{l}\text { S.f, S.n } \\
\text { S.f, S.n } \\
\text { S.f, S.n }\end{array}$ \\
\hline
\end{tabular}



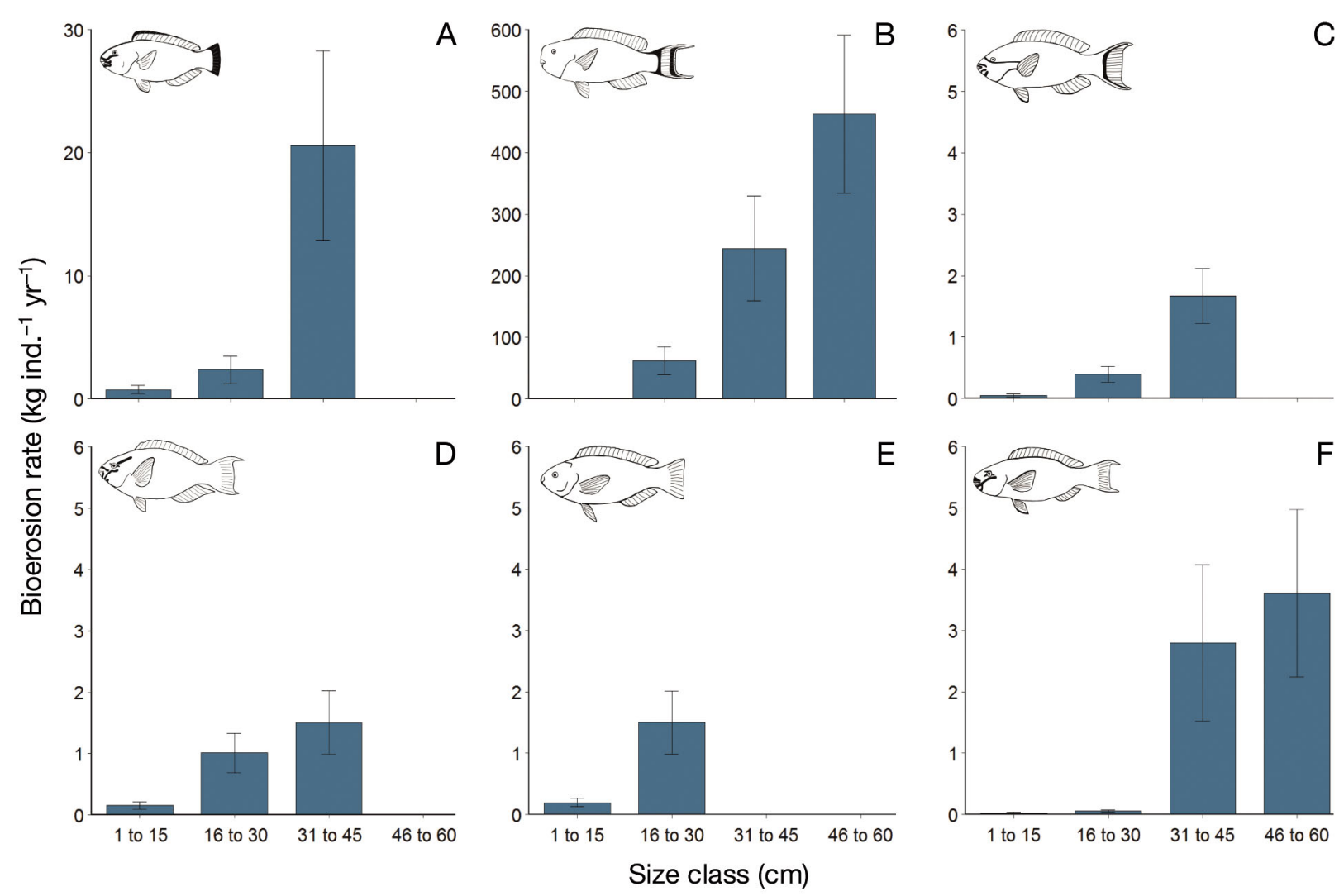

Fig. 6. Annual bioerosion rates by size class for excavators: (A) Chlorurus sordidus and (B) C. strongylocephalus; and scrapers: (C) Scarus frenatus, (D) S. niger, (E) S. psittacus, and (F) S rubroviolaceus. Data are mean \pm cumulative SE. Note the different $y$-axis scales

Table 6. Annual bioerosion rates $\left(\mathrm{kg}_{\mathrm{ind}} \mathrm{.}^{-1} \mathrm{yr}^{-1}\right)$ by size class \pm cumulative error

\begin{tabular}{|llccc|}
\hline Species & \multicolumn{1}{c}{$<15 \mathrm{~cm}$} & $16-30 \mathrm{~cm}$ & $31-45 \mathrm{~cm}$ & $>46 \mathrm{~cm}$ \\
\hline Chlorurus sordidus & $0.741397 \pm 0.341101$ & $2.354055 \pm 1.103516$ & $20.5911 \pm 7.684972$ & \\
C. strongylocephalus & $0.243326 \pm 0.12656$ & $62.45718 \pm 22.76786$ & $244.5914 \pm 84.83448$ & $462.6796 \pm 128.4209$ \\
Scarus rubroviolaceus & $0.023651 \pm 0.015725$ & $0.053061 \pm 0.018697$ & $2.79342 \pm 1.275277$ & $3.607531 \pm 1.368947$ \\
S. frenatus & $0.049804 \pm 0.027727$ & $0.393299 \pm 0.128589$ & $1.665181 \pm 0.44452$ & \\
S. niger & $0.154891 \pm 0.058374$ & $1.009664 \pm 0.324977$ & $1.501203 \pm 0.520661$ & \\
S. psittacus & $0.195101 \pm 0.069385$ & $1.501134 \pm 0.514264$ & & \\
\hline
\end{tabular}

the C. gibbus/strongylocephalus/microrhinos $(\mathrm{CH} 2)$ clade of parrotfish, which one would expect to be comparable, vary between 290 and $1018 \mathrm{~kg}$ ind. ${ }^{-1} \mathrm{yr}^{-1}$ (Bonaldo et al. 2014). This would suggest strong regional variability, and a strong influence of local environmental conditions on parrotfish feeding. Two potential causes of this variability can be suggested: firstly, the different values applied for feeding day length, which is used to account for seasonal variation in daylight hours (Bellwood 1995a); and secondly, substrate density, which varies between $1.4 \mathrm{~g} \mathrm{~cm}^{-3}$ (Alwany et al. 2009) and $2.4 \mathrm{~g} \mathrm{~cm}^{-3}$ (Bellwood 1995a,
Bellwood et al. 2003), based on locally reported rates. As a consequence, some variation in bioerosion rates between regions due to these local environmental factors should be expected. However, another potential cause for variability in bioerosion rate calculations is whether to factor for the proportion of bites that produce observable grazing scars, which some studies include (Bruggemann et al. 1996, Ong \& Holland 2010), but others do not (Bellwood 1995a, Bellwood et al. 2003, Alwany et al. 2009, Morgan \& Kench 2016). Thus, comparisons of parrotfish bioerosion between regions is not straightforward. 
To account for these environmental and methodological differences, and in order to aid bioerosion rate comparisons between regions, we have sought to factor for these issues by producing a table of 'standardised' bioerosion rate calculations (Table 7). To do this, bite rate and grazing scar data have been extracted from the literature, and consistent values applied for length of the feeding day $(11 \mathrm{~h})$, substrate density (regional average of $1.43 \mathrm{~g} \mathrm{~cm}^{-3}$ ), derived from published data summarised in ReefBudget supporting data for the Indo-Pacific (http://geography. exeter.ac.uk/reefbudget/), and the proportions of bites producing scars where they had not been previously included (based on data from the present study; see Table 3). The impact of these conversions is a marked reduction in within-species/clade variability. For example, the observed variability for the $\mathrm{CH} 2$ clade is reduced by $\sim 55 \%$, and for $S$. niger, by $\sim 75 \%$. However, relatively high variability between regions clearly remains.

Three primary reasons are considered likely causes of this remaining variability. Firstly, environmental variables such as depth, wave exposure, and habitat type are known to affect parrotfish bioerosion rates, but are more difficult to control for (Bellwood 1995a, Bruggemann et al. 1996, Bejarano et al. 2017). In addition, local conditions such as water temperature, currents, and the extent of internal substrate erosion may also affect parrotfish bioerosion rates, but are rarely (if ever) reported. Differences in substrate 'softness', or the extent of internal (endolithic) bio- erosion may be especially important in the case of 'exceptionally large' individuals of some scraping species. S. rubroviolaceus, for example, has been observed to produce shallow scars, comparable to that of excavators, in 'soft' or internally bioeroded substrate (Bellwood \& Choat 1990). This may partly explain the difference observed for $S$. rubroviolaceus between the present study (average scar volume for $>45 \mathrm{~cm}$ individuals is $2.4 \pm 0.9 \mathrm{~mm}^{3}$ ) and Ong \& Holland (2010) (average scar volume for $>45 \mathrm{~cm}$ individuals is $93.2 \pm 15.3 \mathrm{~mm}^{3}$ ), a $293 \mathrm{~kg}$ ind. ${ }^{-1} \mathrm{yr}^{-1}$ difference after standardisation, although it is uncertain whether this could result in such substantial variation between regions.

Secondly, as previously mentioned, not all studies provide an estimate of fish size, other than indicating adult size ranges (e.g. Bellwood 1995a, Bellwood et al. 2003, Alwany et al. 2009). As shown in the present study, different sizes of fish erode significantly different quantities of material. We assume in the present study that the largest size classes of parrotfish from studies which provide fish size estimates are most comparable; however, impacts from fishing, for example, may reduce mean fish size on a reef (Taylor et al. 2015), so this assumption may not be true. If terminal-phase males are smaller or larger compared to our assumptions, this may explain some of the observed variability in bioerosion rates. The results of the present study demonstrate the importance of indicating fish size when presenting bioerosion rate data.

Table 7. Standardised bioerosion rates $\left(\mathrm{kg}\right.$ ind.$\left.^{-1} \mathrm{yr}^{-1}\right)$ for 'large' Indo-Pacific parrotfish. Where size class of fish was specified, the largest size class was used for comparison. Data on bites per minute and volume of grazing scars were averaged where there were seasonal or site differences. GBR $=$ Great Barrier Reef

\begin{tabular}{|c|c|c|c|c|c|c|}
\hline Species & $\begin{array}{c}\text { Alwany et al. } \\
\text { (2009) } \\
\text { Red Sea }\end{array}$ & $\begin{array}{c}\text { Bellwood } \\
(1995 a) \\
\text { GBR }\end{array}$ & $\begin{array}{c}\text { Bellwood } \\
\text { et al. (2003) } \\
\text { GBR }\end{array}$ & $\begin{array}{c}\text { Morgan \& } \\
\text { Kench (2016) } \\
\text { Maldives }\end{array}$ & $\begin{array}{c}\text { Ong \& Holland } \\
(2010) \\
\text { Hawaii }\end{array}$ & $\begin{array}{l}\text { This study } \\
\text { Maldives }\end{array}$ \\
\hline \multicolumn{7}{|l|}{ Excavators } \\
\hline Bolbometopon muricatum & & & 3482.6 & & & \\
\hline Cetoscarus bicolor & 222.8 & & & & & \\
\hline Chlororus gibbus & 250.5 & & & & & \\
\hline C. microrhinos & & 582.1 & & & & \\
\hline C. strongylocephalus & & & & 344.1 & & 441.1 \\
\hline C. sordidus & 31.2 & & & 35.5 & & 19.4 \\
\hline C. spilurus & & 9.8 & & & & \\
\hline C. perspicillatus & & & & & 233.1 & \\
\hline \multicolumn{7}{|l|}{ Scrapers } \\
\hline Scarus ferrugineus & 22.1 & & & & & \\
\hline S. frenatus & 24.4 & & & & & 1.6 \\
\hline S. ghobban & 142.2 & & & & & \\
\hline S. niger & 4.8 & & & & & 1.4 \\
\hline S. psittacus & & & & & & 1.5 \\
\hline S. rubroviolaceus & & & & & 296.7 & 3.4 \\
\hline
\end{tabular}


Finally, it might be reasonable to assume that some of this variability is due to the challenges involved with measuring parrotfish feeding characteristics in the field, particular grazing scars. Observations need to be carried out in very close proximity to a grazing parrotfish to observe scar production accurately. Where scar production is observed, scar depth for most species is extremely shallow $(<0.5 \mathrm{~mm})$ and is therefore often within a substrate's natural topographic heterogeneity, and impractical to measure using conventional tools such as callipers. Scar depth assumptions are therefore often applied to most species (e.g. $0.1 \mathrm{~mm}$ for C. sordidus in Bellwood 1995a and the present study), but it is unclear how these assumptions match up to natural variability in scar depth.

Measuring grazing scar production and volume precisely is key to accurately estimating parrotfish bioerosion rates, yet methods to measure these variables differ among studies. For example, there are different approaches with regards to grazing scars that are not visible to the naked eye, which is particularly relevant in parrotfish $<15 \mathrm{~cm}$ (Bellwood 1995a). Indeed, many of the measurements in the $<15 \mathrm{~cm}$ size category in the present study are likely to have been estimated for fish at the larger end of this size range. Some studies have attempted to measure these very small grazing scars under a dissecting microscope, rather than exclude them (e.g. Bellwood 1995a, Bonaldo \& Bellwood 2008). However, such scars are difficult to locate after production, making it challenging to attribute a mark on the substrate to a particular feeding event. These scars also contribute extremely little to bioerosion, and so factoring for the proportion of bites producing observable grazing scars was thus considered a more appropriate and conservative approach here. In addition, while a rectangular prism shape is assumed in the present study, which has been shown to be comparable to laboratory-validated bite scar volumes (Bellwood 1995a, Ong \& Holland 2010), an ellipsoidal shape is assumed in Alwany et al. (2009). Different approaches such as these may result in markedly different outcomes when calculating bioerosion rates. We therefore suggest future research into methods that more accurately estimate grazing scar volumes, or that new methods to validate parrotfish bioerosion rates are required to improve the accuracy of these calculations. This is especially important given the potential for parrotfish bioerosion to influence reef and reef island growth potential in some regions, such as the central Indian Ocean (Perry et al. 2014, 2015a,b).
Future research should also consider regional differences in community-level parrotfish bioerosion, in addition to species comparisons. The high bioerosion and resultant sand generation rates reported in the Maldives (Perry et al. 2015b) may not be replicated where parrotfish biomass or abundance of large excavators is lower, such as in the western Indian Ocean where parrotfish are a target fishery (McClanahan 2011). While the importance of algal grazing by parrotfish is now beginning to be considered in reef management (Jackson et al. 2014), physical functional roles such as bioerosion and sediment production are not yet taken into account. Recent studies have shown that parrotfish may not influence macroalgae and coral cover in all locations (Carassou et al. 2013, Russ et al. 2015); however, bioerosion was not examined in these studies and may not be tightly coupled with grazing pressure. It is therefore unclear whether parrotfish play an important role in the context of reef carbonate budgets in these locations and is something to consider before dismissing the benefits of reduced fishing pressure on parrotfish for reef resilience. Further research into parrotfish bioerosion rates across a broader range of species is also needed, along with investigations into environmental controls on these rates. Expanded data on rates of bioerosion to capture some of this currently missing species diversity would significantly improve the accuracy of reef-scale estimates of parrotfish bioerosion, which is essential to making community-scale estimates of bioerosion, and assessing the growth potential of reefs and reef islands (Perry et al. 2014, 2015b).

Data archive. The research data supporting this publication are openly available from the University of Exeter's institutional repository at: https://doi.org/10.24378/exe.144

Acknowledgements. Research was funded by a Natural Environment Research Council studentship to R.T.Y. (NE/ L002434/1). We thank Ibrahim Sikder and Billal Hossan at Korallionlab Marine Research Station for their hospitality and helpful assistance in the field. We also thank 3 anonymous reviewers and the editor Charles Birkeland for their helpful comments.

\section{LITERATURE CITED}

Afeworki Y, Bruggemann JH, Videler JJ (2011) Limited flexibility in resource use in a coral reef grazer foraging on seasonally changing algal communities. Coral Reefs 30: 109-122

Afeworki Y, Zekeria ZA, Videler JJ, Bruggemann JH (2013) Food intake by the parrotfish Scarus ferrugineus varies seasonally and is determined by temperature, size and territoriality. Mar Ecol Prog Ser 489:213-224 
Alwany MA, Thaler E, Stachowitsch M (2009) Parrotfish bioerosion on Egyptian Red Sea reefs. J Exp Mar Biol Ecol 371:170-176

*Aswani S, Sabetian A (2010) Implications of urbanisation for artisanal parrotfish fisheries in the Western Solomon Islands. Conserv Biol 24:520-530

Bejarano S, Golbuu Y, Sapolu T, Mumby PJ (2013) Ecological risk and the exploitation of herbivorous fish across Micronesia. Mar Ecol Prog Ser 482:197-215

Bejarano S, Jouffray JB, Chollett I, Allen R and others (2017) The shape of success in a turbulent world: wave exposure filtering of coral reef herbivory. Funct Ecol 31:1312-1324

Bellwood DR (1995a) Direct estimate of bioerosion by two parrotfish species, Chlorurus gibbus and C. sordidus, on the Great Barrier Reef, Australia. Mar Biol 121:419-429

Bellwood DR (1995b) Carbonate transport and within-reef patterns of bioerosion and sediment release by parrotfishes (family Scaridae) on the Great Barrier Reef. Mar Ecol Prog Ser 117:127-136

Bellwood DR (1996) Production and reworking of sediment by parrotfishes (family Scaridae) on the Great Barrier Reef, Australia. Mar Biol 125:795-800

* Bellwood DR, Choat H (1990) A functional analysis of grazing in parrotfishes (family: Scaridae): the ecological implications. Environ Biol Fishes 28:189-214

Bellwood DR, Hoey AS, Choat JH (2003) Limited functional redundancy in high diversity systems: resilience and ecosystem function on coral reefs. Ecol Lett 6:281-285

Bellwood DR, Hughes TP, Folke C, Nyström M (2004) Confronting the coral reef crisis. Nature 429:827-833

Bellwood DR, Hoey A, Hughes TP (2012) Human activity selectively impacts the ecosystem roles of parrotfishes on coral reefs. Proc R Soc B 279:1621-1629

Birkeland C, Dayton PK (2005) The importance in fishery management of leaving the big ones. Trends Ecol Evol 20:356-358

Bonaldo RM, Bellwood DR (2008) Size-dependant variation in the functional role of the parrotfish Scarus rivulatus on the Great Barrier Reef, Australia. Mar Ecol Prog Ser 360: 237-244

Bonaldo RM, Bellwood DR (2009) Dynamics of parrotfish grazing scars. Mar Biol 156:771-777

Bonaldo RM, Krajewski JP, Sazima C, Sazima I (2006) Foraging activity and resource use by three parrotfish species at Fernando de Noronha Archipelago, tropical West Atlantic. Mar Biol 149:423-433

Bonaldo RM, Hoey AS, Bellwood DR (2014) The ecosystem roles of parrotfishes on tropical reefs. Oceanogr Mar Biol Annu Rev 52:81-132

* Bruggemann JH, van Oppen MJH, Breeman AM (1994a) Foraging by the stoplight parrotfish Sparisoma viride. I. Food selection in different, socially determined habitats. Mar Ecol Prog Ser 106:41-55

Bruggemann JH, Begeman J, Bosma EM, Verburg P, Breeman AM (1994b) Foraging by the stoplight parrotfish Sparisoma viride. II. Intake and assimilation of food, protein and energy. Mar Ecol Prog Ser 106:57-71

B Bruggemann JH, van Kessel AM, van Rooij JM, Breeman AM (1996) Bioerosion and sediment ingestion by the Caribbean parrotfish Scarus vetila and Sparisoma viride: implications of fish size, feeding mode and habitat use. Mar Ecol Prog Ser 134:59-71

Carassou L, Léopold M, Guillemot N, Wantiez L, Kulbicki M (2013) Does herbivorous fish protection really improve coral reef resilience? A case study from New Caledonia
(South Pacific). PLOS ONE 8:e60564

* Carr A, Tibbetts IR, Kemp A, Truss R, Drennan J (2006) Inferring parrotfish (Teleostei: Scaridae) pharyngeal mill function from dental morphology, wear, and microstructure. J Morphol 267:1147-1156

Choat JH, Klanten OS, Herwerden LV, Robertson DR, Clements KD (2012) Patterns and processes in the evolutionary history of the parrotfishes (Family Labridae). Biol J Linn Soc 107:529-557

Clements KD, German DP, Piché J, Tribollet A, Choat JH (2016) Integrating ecological roles and trophic diversification on coral reefs: multiple lines of evidence identify parrotfish as microphages. Biol J Linn Soc, doi:10.1111/ bij.12914

* Ferrario F, Beck MW, Storlazzi CD, Micheli F, Shepard CC, Airoldi L (2014) The effectiveness of coral reefs for coastal hazard risk reduction and adaptation. Nat Commun 5:3794

*Fox RJ, Bellwood DR (2007) Quantifying herbivory across a coral reef depth gradient. Mar Ecol Prog Ser 339:49-59

Frydl P, Stearn CW (1978) Rate of bioerosion by parrotfish in Barbados reef environments. J Sediment Petrol 48: 1149-1158

Glynn PW (1997) Bioerosion and coral reef growth: a dynamic balance. In: Birkeland $\mathrm{C}$ (ed) Life and death of coral reefs. Chapman \& Hall, New York, NY, p 68-95

Gygi RA (1975) Sparisoma viride (Bonnaterre), the Stoplight Parrotfish, a major sediment producer on coral reefs of Bermuda. Eclogae Geol Helv 68:327-359

* Hughes TP, Kerry JT, Álvarez-Noriega M, Álvarez-Romero JG and others (2017) Global warming and recurrent mass bleaching of corals. Nature 543:373-377

Jackson JBC, Donovan MK, Cramer KL, Lam W (eds) (2014) Status and trends of Caribbean coral reefs: 1970-2012. Global Coral Reef Monitoring Network, IUCN, Gland

Kench PS, Brander RW (2006) Response of reef island shorelines to seasonal climate oscillations: South Maalhosmadulu atoll, Maldives. J Geophys Res 111:F01001

* Lokrantz J, Nyström M, Thyresson M, Johansson C (2008) The non-linear relationship between body size and function in parrotfishes. Coral Reefs 27:967-974

Long SP, Humphries S, Falkowski PG (1994) Photoinhibition of photosynthesis in nature. Annu Rev Plant Physiol Plant Mol Biol 45:633-662

* Lugo-Fernández A, Roberts HH, Suhayda JN (1998) Wave transformations across a Caribbean fringing-barrier coral reef. Cont Shelf Res 18:1099-1124

* McClanahan TR (1994) Kenyan coral reef lagoon fish: effects of fishing, substrate complexity, and sea urchins. Coral Reefs 13:231-241

McClanahan TR (2011) Coral reef fish communities in management systems with unregulated fishing and small fisheries closures compared with lightly fished reefMaldives vs. Kenya. Aquat Conserv 21:186-198

* Moberg F, Folke C (1999) Ecological goods and services of coral reef ecosystems. Ecol Econ 29:215-233

* Morgan KM, Kench PS (2012) Skeletal extension and calcification of reef-building corals in the central Indian Ocean. Mar Environ Res 81:78-82

* Morgan KM, Kench PS (2016) Parrotfish erosion underpins reef growth, sand talus development and island building in the Maldives. Sediment Geol 341:50-57

*Mumby PJ (2006) The impact of exploiting grazers (Scaridae) on the dynamics of Caribbean coral reefs. Ecol Appl 16:747-769 
Ogden JC (1977) Carbonate sediment production by parrot fish and sea urchins on Caribbean reefs. Am Assoc Pet Geol Stud Geol 4:281-288

* Ong L, Holland KN (2010) Bioerosion of coral reefs by two Hawaiian parrotfishes: species, size differences and fishery implications. Mar Biol 157:1313-1323

Perry CT, Hepburn LJ (2008) Syn-depositional alteration of coral reef framework through bioerosion, encrustation and cementation: taphonomic signatures of reef accretion and reef depositional events. Earth Sci Rev 86:106-144

Perry CT, Morgan KM (2017) Bleaching drives collapse in reef carbonate budgets and reef growth potential on southern Maldives reefs. Sci Rep 7:40581

Perry CT, Spencer T, Kench PS (2008) Carbonate budgets and reef production states: a geomorphic perspective on the ecological phase-shift concept. Coral Reefs 27:853-866

* Perry CT, Murphy GN, Kench PS, Edinger EN, Smithers SG, Steneck RS, Mumby PJ (2014) Charging dynamics of Caribbean reef carbonate budgets: emergence of reef bioeroders as critical controls on present and future reef growth potential. Proc R Soc B 281:20142018

* Perry CT, Murphy GN, Graham NAJ, Wilson SK, Januchowski-Hartley FA, East HK (2015a) Remote coral reefs can sustain high growth potential and may match future sea-level trends. Sci Rep 5:18289

Perry CT, Kench PS, O' Leary MJ, Morgan KM, Januchowski-Hartley F (2015b) Linking reef ecology to island building: Parrotfish identified as major producers of island-building sediment in the Maldives. Geology 43: 503-506

Editorial responsibility: Charles Birkeland, Honolulu, Hawaii, USA
Perry CT, Morgan KM, Yarlett RT (2017) Reef habitat type and spatial extent as interacting controls on platformscale carbonate budgets. Front Mar Sci 4:185

Ruckelshaus M, Doney SC, Galindo HM, Barry JP and others (2013) Securing benefits for society in the face of climate change. Mar Policy 40:154-159

* Russ GR, Questel SLA, Rizzari JR, Alcala AC (2015) The parrotfish-coral relationship: refuting the ubiquity of a prevailing paradigm. Mar Biol 162:2029-2045

Scoffin TP (1992) Taphonomy of coral reefs: a review. Coral Reefs 11:57-77

Scoffin TP, Stearn CW, Boucher D, Frydl P, Hawkins CM, Hunter IG, MacGeachy JK (1980) Calcium carbonate budget of a fringing reef on the west coast of Barbados. Part II-erosion, sediments and internal structure. Bull Mar Sci 30:475-508

Stearn CW, Scoffin TP, Martindale W (1977) Calcium carbonate budget of a fringing reef on the west coast of Barbados. I. Zonation and productivity. Bull Mar Sci 27: 479-510

Takahashi S, Murata N (2008) How do environmental stresses accelerate photoinhibition? Trends Plant Sci 13: 178-182

* Taylor BM, Lindfield SJ, Choat JH (2015) Hierarchical and scale-dependent effects of fishing pressure and environmental on the structure and size distribution of parrotfish communities. Ecography 38:520-530

* Zemke-White LW, Choat JH, Clements KD (2002) A reevaluation of the diel feeding hypothesis for marine herbivorous fishes. Mar Biol 141:571-579

Submitted: July 17, 2017; Accepted: January 9, 2018 Proofs received from author(s): March 2, 2018 